\title{
Impact of fragmentation on tree diversity, density and structure of Pentadesma butyracea Sabine Clusiaceae population in Benin (West-Africa)
}

\author{
M'Mouyohoun KOUAGOU*, E. B. Olivier AHOUANDJINOU, S. S. Honoré BIAOU, \\ N. Timothée KEITA and K. Armand NATTA
}

Laboratory of Ecology, Botany and Plant Biology (LEB), University of Parakou (UP), Republic of Benin.

*Corresponding author; E-mail: mkouagou@gmail.com

\section{ACKNOWLEDGEMENTS}

This work was financially supported by the International Foundation for Science (Grant $n^{\circ}$ D/6092-1 to the first author). IDEA WILD provided equipment to the first author.

\begin{abstract}
Fragmentation affects population structure and tree diversity. However, the main causes of fragmentation and their consequences on population structure are still unclear. This study evaluated some causes of gallery forest (GFs) fragmentation and their effect on Pentadesma butyracea population structures in Benin. Twelve $P$. butyracea GFs were selected in semi-arid and sub-humid ecological zones. Populations were identified varying fragmentation indicators (gallery width, distance to the nearest population, current area, shape of GFs and rate of area loss during the last three decades) to assess the species diversity, tree densities and shape of diameter class distribution (SDCD) of trees. Generalized linear regression was used to test the effect of fragmentation on species diversity, density and SDCD. The proximity of villages, farms to GFs increased fruit harvest rate and GFs area reduction. Interaction between gallery width, area loss rate and ecological zone had a significant effect on species diversity, density and marginally on SDCD. The results are valuable in the perspective that they showed the importance of the combined effect of habitat fragmentation and provide a better understanding of the actions to be considered for sustainable conservation of GFs and $P$. butyracea trees.
\end{abstract}

(C) 2018 International Formulae Group. All rights reserved.

Keywords: Fragmentation, gallery forest, Pentadesma butyracea, ecological zone, population structure, tree diversity.

\section{INTRODUCTION}

Habitat fragmentation is the transformation of a continuous habitat into multiple smaller and spatially isolated remnants (Digiovinazzo et al., 2010). Fragmentation and habitat loss are recognized as major biodiversity threats (Fahrig 2003; Yeo et al., 2013). Although there is a diversity of natural resources, their habitats face multiple disturbances (Gaoue et al., 2017) that lead to fragmentation and habitat loss. Several factors are considered as determinants of fragmentation. The most important are wildfire, uncontrolled logging, agriculture, pasture (Adjonou et al., 2010; Maazou et al., 
2017) and the collection of multi-use species (Yeo et al., 2013).

These human activities modified ecological processes as well as the functioning of populations and their interactions (Brudvig et al., 2015). According to Yeo et al. (2013) fragmentation occurs when intact block subdivide to give many smaller habitat fragments more spatially isolated. This mechanism could have serious consequences on ecosystem, including disturbances in the process of pollination and seed dispersal (Barrios Roque et al., 2016); reducing the species diversity of ecological communities and population size, thus increasing the risk of local extinction (Fahrig, 2003). Species richness is a function of the habitat fragment size and their degree of isolation. Reduced area and spatial isolation can reduce species diversity (Barrios Roque et al., 2016). In addition, the proximity of farms and habitations could also reduce the size of the forest fragment and consequently affect ecosystem wealth. At other times, forest galleries that were considered as marginal lands are taken over by farmers (Yabi et al., 2017). These are subject to shifting cultivation, extensive livestock grazing, firewood collection, charcoal production, commercial logging and harvest of non-timber forest products and human occupations (Marie et al., 2011). These induce the landscape fragmentation and lead to the enormous loss of composition, structure and diversity of plant and animal communities (Dan et al., 2012; Yabi et al., 2017).

Gallery forests are unique ecosystem in Benin similar to dense forest (Natta, 2003). Unfortunately they are reducing and are more and more isolated due to agriculture and fire (Natta, 2003; Avocevou-ayisso, 2011) and this may be a threat of biodiversity decline (Yabi et al., 2017). Pentadesma butyracea Sabine is a gallery forest tree species in Benin (Natta, 2003) threatened by overexploitation and habitat size reduction (Avocevou-ayisso, 2011; Gaoue et al., 2017). It is important to identify the main determinants of the fragmentation of gallery forests in order to guide planning and conservation policies.
Thus, the evaluation of the relationship among anthropogenic pressures, the proximity of farms and villages to gallery forest and the gallery forest fragmentation on the one hand and with structure, biodiversity and composition on the other hand remains a research question essential to be approached in the perspective of having a good scientific database. This study investigated main causes of gallery forest fragmentation and their effect on Pentadesma butyracea Sabine gallery forest population structure and tree diversity in Benin, West-Africa.

\section{MATERIALS AND METHODS Study area}

This study was conducted in the Republic of Benin between $6^{\circ}-12^{\circ} 50$ 'N and $1^{\circ} 3^{\circ} 40$ 'E in West Africa. It covers the Sudano-Guinean (sub-humid) transition zone $\left(7^{\circ} 30-9{ }^{\circ} 30 \mathrm{~N}\right)$, characterized by a rainfall between 1100 and $1200 \mathrm{~mm} /$ year. It has ferruginous soil on alkaline rocks. There are dry forests, wooded savannas and gallery forests (Adomou, 2005) and the Sudanian (semi-arid) zone $\left(9^{\circ} 30-12^{\circ} \mathrm{N}\right)$, characterized by a rainfall between $800-1100 \mathrm{~mm} /$ year. It has a tropical ferruginous soil; there are wooded savannas and riparian forests (Adomou, 2005). P. butyracea, very scarce throughout the country is found in some gallery forests (Natta, 2003). In the SudanoGuinean zone it is found in the town of Bassila and near the village of Agbassa, town of Tchaourou between the parallels $8^{\circ}$ and $9^{\circ}$ $50 \mathrm{~N}$ and between $1^{\circ}$ and $3^{\circ} 40^{\prime} \mathrm{E}$. In Sudanian zone, $P$. butyracea was found in the town of Boukombe, Natitingou, Kouandé, Tanguiéta, Toucountouna between $9^{\circ} 53 \mathrm{~N}$ and $11^{\circ} 23 \mathrm{~N}$ on the one hand and in the town of Kandi and Ségbana between $0^{\circ} 45$ 'E and $2^{\circ} 8{ }^{\prime} \mathrm{E}$ on the other hand (Figure 1).

\section{Study species}

Pentadesma butyracea is a wild tree species native to the dense evergreen forests of West Africa (Sama et al., 2007). It is a mesophanérophyte with cylindrical barrel and straight up to $80 \mathrm{~cm}$ in diameter (Sama et al., 2007). In Benin, P. butyracea occurs in the 
gallery forests of the Sudano-Guinean and Sudanian zones (Natta, 2003). It is a multipurpose uses species with aggregative distribution whose fruits are berries, more or less globose, weighing from 50 to $1500 \mathrm{~g}$ with 1 to 25 seeds of variable shape and size (Avocevou-ayisso, 2011; Ewédjè et al., 2012). $P$. butyracea can reproduce by seed and root (Avocevou-ayisso, 2011).

\section{Methods}

\section{Data collection}

The sites of study were chosen based on Natta et al. (2011a, 2011b). They found 76 sites of $P$. butyracea in Sudano-guinean zone (Natta et al., 2011b) and 38 in Sudanian zone (Natta et al., 2011a). We used coordinates of sites of $P$. butyracea recorded by Natta, (2003), Natta et al. (2011a, 2011b) for preliminary survey. Local people helped to identify new sites. After the first survey, 25 and 35 populations were found in Sudanoguinean and Sudanian zones respectively. Then, six populations were randomly selected in each ecological zone and the nearest distance between populations was estimated.

One plot of 1 ha was established in each population. Each plot was installed in the direction of the river and according to the width of the gallery forest to remain in the physiognomic uniformity of the gallery forest. Thus to test the effect of the proximity of populations of $P$. butyracea with farms and villages on fragmentation indicators, the distance between each population and the nearest farm, the nearest village and the nearest car road were recorded. Then, the current area and perimeter of each population were measured to calculate the shape index of each gallery forest. To analyze the impact of fragmentation on floristic diversity and density, the floristic list of all species with diameter at breast height $(\mathrm{dbh}) \geq 5 \mathrm{~cm}$ (Dicko et al., 2016) was recorded and the number of all trees species was counted as well as the number of $P$. butyracea trees. The diameter of $P$. butyracea was measured for all individuals of $\mathrm{dbh} \geq 2 \mathrm{~cm}$. The intensity of fruit harvest was calculated per population as the ratio between the estimated harvested fruit number and the total fruit number produced by all trees in that population. Local women leave fruit peduncle under tree after seed extraction. This made easy the estimation of the harvested fruit number. The rate of fruits harvest per population was evaluated in 2012, 2015, 2016 and 2017. The fruit number per tree was first evaluated by direct counting during the fruit-ripening period, FebruaryMarch. Fallen fruit number per population was counted. Local people knowledge were used to confirm the intensity of fruit harvest (Low, medium and high).

\section{Statistical analysis}

To test the effect of the proximity of the populations of $P$. butyracea to farms, villages and roads on the indicators of fragmentation of $P$. butyracea populations, we used Spearman correlation analysis because these variables did not follow a normal distribution $(p<0.05)$. Correlation analyzes were performed with the Hmisc package. Fruit harvest rate was calculated as the ratio between numbers of fruits harvested in each population over its total number of fruits (Gaoue et al., 2017). The shape index, perimeter-to-area ratio of each population was calculated. The equitability index of Piélou was calculated to measure the distribution of individuals within species, regardless of the species richness of different populations;

$$
E q=\frac{H^{\prime}}{\log _{2} S}
$$

$H^{\prime}$, an index of Shannon was calculated to quantify the heterogeneity of the biodiversity of a study environment and thus to observe a change over time. It varies from 0 to $\operatorname{lnS}$ and is calculated based on the following formula:

$$
H^{\prime}=-\sum_{i=1}^{s} \frac{n_{i}}{N} * \log _{2} \frac{n_{i}}{N}
$$

It is expressed as a biomass information unit with, $\mathrm{ni}=$ the number of trees of species $\mathrm{i}$, and $\mathrm{N}=$ sum of $\mathrm{S}$ species constituting the stand. To test the effect of fragmentation on the diameter structure of $P$. butyracea gallery forest trees, the shape parameter (c) of Weibull distribution with three parameter $(\mathrm{a}, \mathrm{b}$ and $\mathrm{c})$ was calculated 
(Salako et al., 2013). This distribution has the function of probability density:

$$
f(x)=\frac{c}{b}\left(\frac{x-1}{b}\right)^{c-1} \exp \left[-\left(\frac{x-1}{b}\right)^{c}\right]
$$

$\mathrm{x}=$ diameter of the trees; $\mathrm{f}(\mathrm{x})=$ probability density value at point $\mathrm{x} ; a=$ position parameter $(\mathrm{a}=5 \mathrm{~cm}$ for trees diameter of all species combined and $\mathrm{a}=2 \mathrm{~cm}$ for $P$. butyracea tree diameter); $b=$ scale or size parameter; it is related to the central value of the diameters of the trees of the considered stand and $c=$ shape parameter related to the structure in diameter (SDCD). The shape parameter for all tree species and for $P$. butyracea trees was calculated. The beta regression was used to test the effect of gallery width and habitat area loss on the Piélou index with the betareg package (Cribari-Neto and Zeileis, 2010). Linear regression was used to test the effect of gallery width and habitat area loss on SDCD and binomial negative generalized linear regression was used to assess the impact of gallery width and habitat area loss on species diversity, on density of all tree species and of $P$. butyracea trees. All statistical analyzes were performed in $\mathrm{R}$ version 3.4.1 ( $\mathrm{R}$ Core Team, 2017).

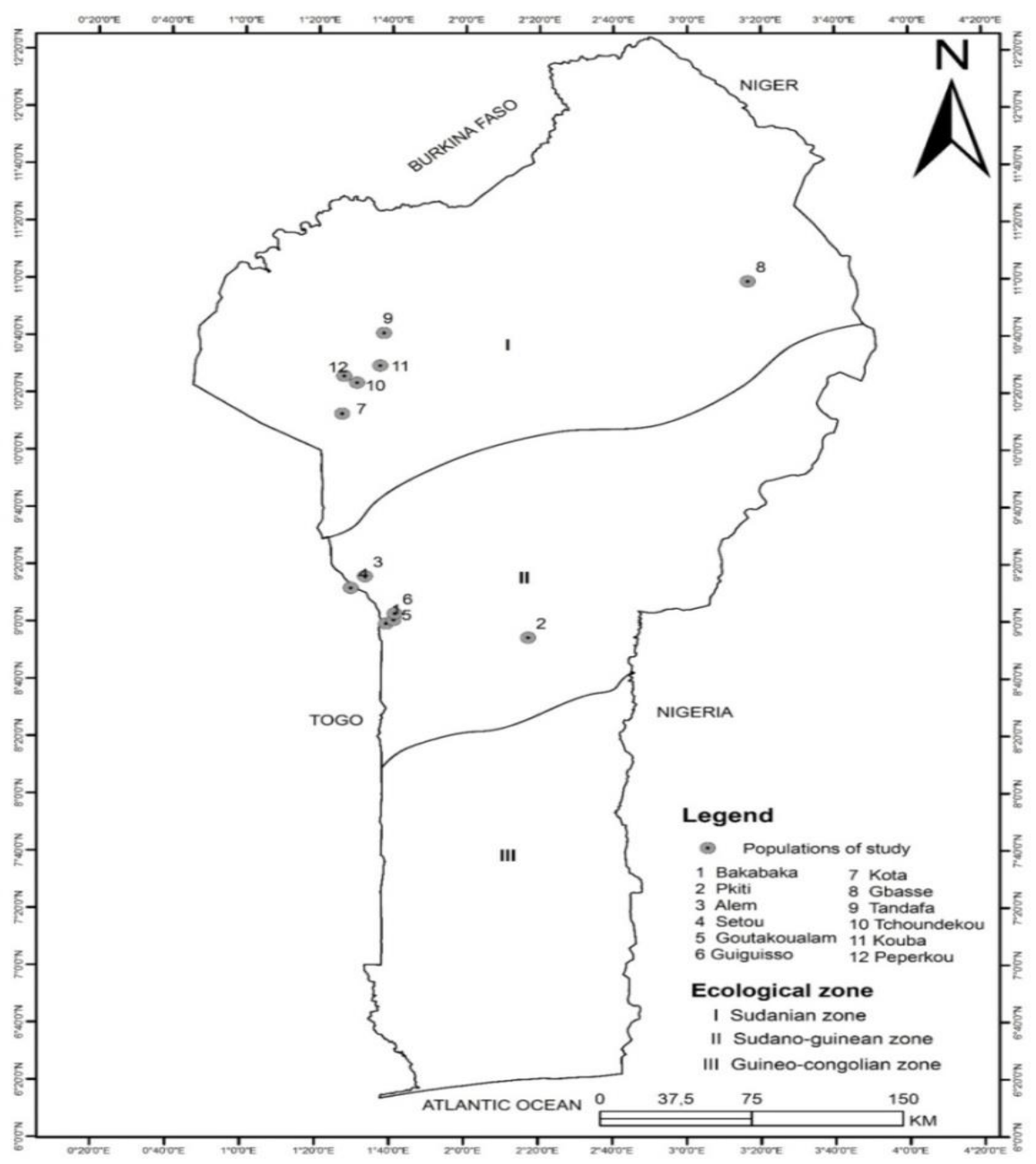

Figure 1: Distribution of $12 P$. butyracea populations (GFs of $P$. butyracea) selected in two ecological zones of Benin. 


\section{RESULTS}

Relationship between potential causes of fragmentation and fragmentation indices

The distance village- gallery forest (GFs) of P. butyracea is strongly correlated with the distance farm- GFs of $P$. butyracea (r $=0.598, \mathrm{p}=0.04)$, with the distance car roadGFs of $P$. butyracea $(\mathrm{r}=0.636, \mathrm{p}=0.026)$ and with fruit harvest rate (Figure 2A, $\mathrm{r}=-0.583$, $\mathrm{p}=0.042$ ). The distance farm- GFs of $P$. butyracea was negatively correlated with fruit harvest rate (Figure 2B, $\mathrm{r}=-0.841, \mathrm{P}=0.001$ ) and also negatively correlated with the rate of GFs area loss $(r=-0.809, \mathrm{p}=0.003)$. The distance car road- GFs of $P$. butyracea is positively correlated with the distance motorcycle road- GFs of $P$. butyracea ( $\mathrm{r}=$ $0.74, \mathrm{p}=0.006$ ). The distance farm- GFs of $P$. butyracea is positively correlated with the current gallery area (Figure 2C, r $=0.612, \mathrm{p}=$ 0.046).

The width of the GFs of $P$. butyracea is negatively correlated with the proximity of the different $P$. butyracea GFs $(\mathrm{r}=-0.69, \mathrm{p}=$ $0.013)$, with the shape index of GFs $(r=-0.90$; $\mathrm{p}<0.0001)$ and positively with the current area of GFs of P. butyracea $(\mathrm{r}=0.88, \mathrm{p}$ $<0.0001)$. The distance to the nearest population of $P$. butyracea was correlated with the shape index of gallery forests $(\mathrm{r}=$ $0.7, \mathrm{p}=0.017)$. The current area of GFs of $P$. butyracea is negatively correlated with their shape index $(r=-0.71, p=0.015)$ and with their area loss rate $(r=-0.61, p=0.048)$. The shape index is positively correlated with the loss of the area of GFs of P. butyracea $(\mathrm{r}=$ $0.62, \mathrm{p}=0.044)$. The fruit harvest rate was positively correlated with the loss of area $(\mathrm{r}=$ $0.82, \mathrm{p}=0.002$ ).
Effect of fragmentation on species diversity, tree density and size class distribution (SDCD)

There was no fragmentation index that was correlated with Shannon's index and Piélou's equitability (Table 1). However, the shape of the gallery forest of $P$. butyracea was marginally correlated with the specific diversity $(r=-0.573, p=0.066$, Figure $3 \mathrm{~A})$. The width of the gallery was also marginally correlated with specific diversity $(r=0.524, p$ $=0.08$, Figure $3 \mathrm{~B})$. There was no significant linear correlation between fragmentation indices and the density of $P$. butyracea and between fragmentation indices and the SDCD ( $p>0.05$, Table 1). The gallery width and the rate of gallery area loss affected differently population structure (SDCD) of $P$. butyracea (Table 2). The reduction of gallery width had a significant effect on the number of species in Sudano-guinean zone than in Sudanian zone $(\mathrm{Z}=2.17, \mathrm{p}=0.03)$. Equitability of Pielou was low in Sudano-guinean zone than in Sudanian zone (Table 3, $\mathrm{Z}=-2.78, \mathrm{p}=0.0054$ ) and decreased in Sudano-guinean zone when fragmentation led to a decrease of gallery width $(\mathrm{Z}=3.52, \mathrm{p}=0.0004)$. All tree species density significantly increased with an increase of gallery width $(\mathrm{Z}=3.26, \mathrm{p}=0.0011)$ but decreased in Sudano-guinean zone with an increase of gallery width $(\mathrm{Z}=-2.75,006)$. The effect of habitat area loss depended on ecological zone. The density of $P$. butyracea in Sudano-guinean zone was negatively affected by area loss than in Sudanian zone $(\mathrm{Z}=-3.33, \mathrm{p}=0.0008)$. The SDCD of all tree species was significantly higher in Sudanoguinean zone than in Sudanian zone (Table 3, $\mathrm{t}=2.72, \mathrm{p}=0.0298)$. It increase with the increase of rate of area loss $\quad(\mathrm{t}=2.85$, $\mathrm{Z}=0.0247)$. There was no effect of fragmentation on SDCD of $P$. butyracea (Table 2). 

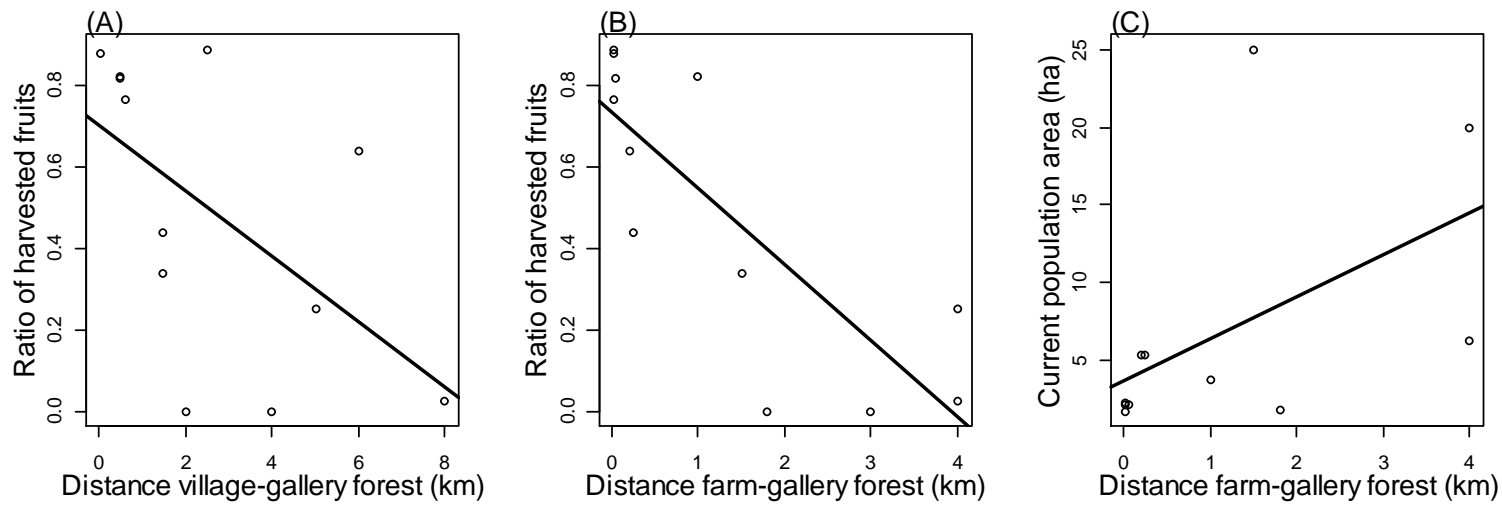

Figure 2: Relationships between distance villages - gallery forest and fruit harvest rate (A); distance farms - gallery forest and fruit harvest rate (B); distance farm-gallery forest and current gallery area (C).
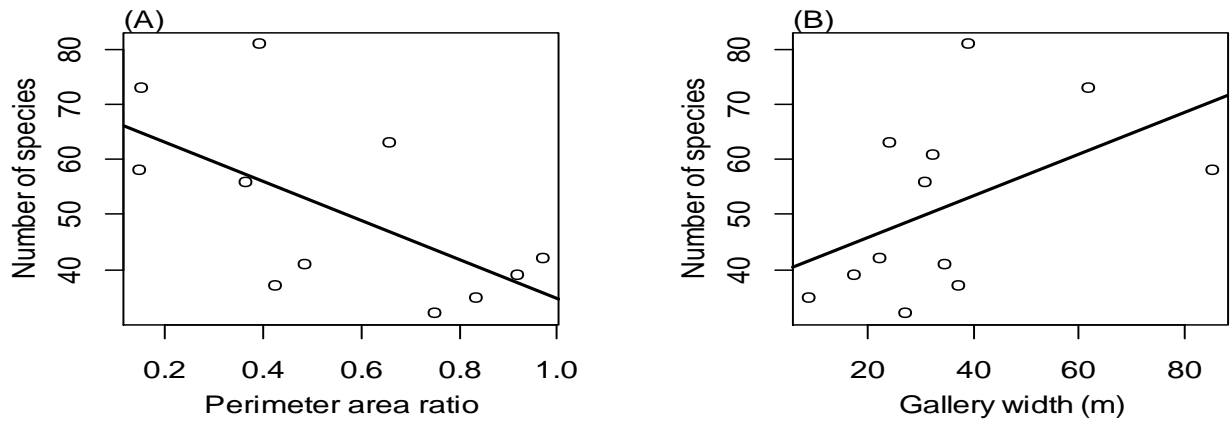

Figure 3: Relationships between gallery shape (A) and width (B) and number of species.

Table 1: Spearman correlation coefficients (under the diagonal) among the gallery width (Gal.W, $\mathrm{m}$ ), distance to the nearest population (D.near, $\mathrm{km}$ ), current area (area, ha), perimeter area ratio (Per.area), rate of area loss for the three last decades (los.area), species diversity (S), equitability of Piélou (P), density of all trees (Dty), density of P. butyracea trees (Dty.P), shape parameter of diameter class distribution of all trees (C.all.T) and of P. butyracea trees (C.Penta) and P-values (above the diagonal); significant correlations are in bold.

\begin{tabular}{lccccccccccc}
\hline & Gal.W & D.near & Area & Per.area & los.area & S & P & Dty & Dty.P & C.all.T & C.Penta \\
\hline Gal.W & & $\mathbf{0 . 0 1 3}$ & $\mathbf{0 . 0 0 0}$ & $\mathbf{0 . 0 0 0}$ & 0.113 & 0.080 & 0.851 & 0.697 & 0.127 & 0.402 & 0.585 \\
D.near & -0.69 & & 0.112 & $\mathbf{0 . 0 1 7}$ & 0.485 & 0.105 & 0.188 & 0.570 & 0.841 & 0.687 & 0.991 \\
Area & 0.88 & -0.51 & & $\mathbf{0 . 0 1 5}$ & $\mathbf{0 . 0 4 8}$ & 0.133 & 0.920 & 0.729 & 0.124 & 0.989 & 0.989 \\
Per.area & -0.90 & 0.70 & -0.71 & & $\mathbf{0 . 0 4 4}$ & 0.066 & 0.275 & 0.915 & 0.483 & 0.564 & 0.769 \\
los.area & -0.51 & 0.24 & -0.61 & 0.62 & & 0.536 & 0.307 & 0.509 & 0.984 & 0.517 & 0.228 \\
S & 0.52 & -0.49 & 0.48 & -0.57 & -0.21 & & 0.957 & $\mathbf{0 . 0 4 2}$ & 0.449 & 0.428 & 0.640 \\
P & 0.06 & -0.43 & -0.04 & -0.38 & -0.36 & -0.02 & & $\mathbf{0 . 0 1 9}$ & 0.101 & 0.695 & 0.252 \\
Dty & 0.13 & 0.18 & 0.12 & -0.04 & 0.22 & 0.59 & -0.69 & & 0.089 & 0.578 & 0.712 \\
Dty.P & 0.47 & -0.07 & 0.5 & -0.24 & 0.01 & 0.24 & -0.52 & 0.51 & & 0.536 & $\mathbf{0 . 0 4 6}$ \\
C.all.T & 0.27 & -0.13 & 0.01 & -0.2 & 0.22 & 0.25 & 0.14 & 0.18 & 0.20 & & $\mathbf{0 . 0 2 2}$ \\
C.Penta & 0.18 & 0.01 & -0.01 & 0.10 & 0.4 & -0.15 & -0.38 & 0.12 & 0.59 & 0.65 & \\
\hline
\end{tabular}


Table 2: Effect of rate of population area loss (los.area), gallery width (Gal.W) in two contrasted ecological zones (Sudanian, S and Sudano-guinean, SG) on number of species (S), index of Pielou, densities and SDCD of all tree species (Shape all, C.all.T) and of P. butyracea (Shape PB, C.Penta) trees.

\begin{tabular}{|c|c|c|c|c|c|}
\hline Responses & Variables & Estimate & Std.Error & $\mathrm{z}$ value & $\operatorname{Pr}(>|z|)$ \\
\hline \multirow{4}{*}{$\begin{array}{l}\text { Total number of } \\
\text { species }(S)\end{array}$} & Intercept & 3.422 & 0.285 & 11.99 & $<2 \mathrm{e}-16^{* * *}$ \\
\hline & los.area & 0.004 & 0.003 & 1.22 & $0.22^{\mathrm{ns}}$ \\
\hline & Zone-S:Gal.W & 0.007 & 0.009 & 0.70 & $0.48^{\mathrm{ns}}$ \\
\hline & Zone-SG:Gal.W & 0.010 & 0.005 & 2.17 & $0.03^{*}$ \\
\hline \multirow{5}{*}{ Pielou index } & Intercept & 3.645 & 1.072 & 3.40 & $0.0007 * * *$ \\
\hline & Gal.W & -0.127 & 0.035 & -3.62 & $0.0003 * * *$ \\
\hline & los.area & -0.007 & 0.008 & -0.88 & $0.3775^{\mathrm{ns}}$ \\
\hline & Zone-SG & -2.666 & 0.960 & -2.78 & $0.0055^{* *}$ \\
\hline & Zone-SG: Gal.W & 0.126 & 0.036 & 3.52 & $0.0004 * * *$ \\
\hline \multirow{4}{*}{$\begin{array}{l}\text { All tree density } \\
\text { (Dty) }\end{array}$} & Intercept & 5.272 & 0.307 & 17.15 & $<2 \mathrm{e}-16^{* * *} *$ \\
\hline & Gal.W & 0.034 & 0.010 & 3.26 & $0.0011 * *$ \\
\hline & los.area & 0.008 & 0.004 & 2.16 & $0.0306^{*}$ \\
\hline & Zone-SG: Gal.W & -0.022 & 0.008 & -2.75 & $0.0060 * *$ \\
\hline \multirow{4}{*}{$\begin{array}{l}\text { P. butyracea tree } \\
\text { density (Dty.P) }\end{array}$} & Intercept & 2.757 & 0.495 & 5.57 & $2.6 \mathrm{e}-08 * * *$ \\
\hline & los.area & 0.036 & 0.009 & 4.20 & $2.7 \mathrm{e}-05 * * *$ \\
\hline & Zone-SG & 2.086 & 0.545 & 3.83 & $0.0001 * * *$ \\
\hline & los.area:Zone-SG & -0.033 & 0.01 & -3.33 & $0.0009 * * *$ \\
\hline \multirow{4}{*}{ Shape all (C.all.T) } & Intercept & 0.674 & 0.148 & 4.56 & $0.0026^{* *}$ \\
\hline & los.area & 0.007 & 0.003 & 2.85 & $0.0247 *$ \\
\hline & Zone-SG & 0.451 & 0.166 & 2.72 & $0.0298 *$ \\
\hline & los.area:Zone-SG & -0.007 & 0.003 & -2.19 & 0.0651 \\
\hline Shape PB (C.Penta) & Intercept & 0.871 & 0.042 & 20.9 & $3.3 \mathrm{e}-10 * * *$ \\
\hline
\end{tabular}

Table 3: Means and standard errors (SE) of gallery width (Gal.W, m), distance to the nearest population (D.near, $\mathrm{km}$ ), current area (area, ha), perimeter area ratio (Per.area), rate of area loss for the three last decades (los.area, \%), species diversity (S), equitability of Piélou (P), density of all trees (Dty), density of $P$. butyracea trees (Dty.P), shape parameter of diameter class distribution of all trees (C.all.T) and of P. butyracea trees (C.Penta) for all populations (All) and between ecological zones (SG: Sudano-guinean and S: Sudanian).

\begin{tabular}{lcccccccccccc}
\hline Zone & Statistics & Gal.W & D.near & Area & Per.area & Los.area & S & P & Dty & Dty.P & C.all.T & C.penta \\
\hline \multirow{2}{*}{ All } & Mean & 35.01 & 7.25 & 6.9 & 0.55 & 0.42 & 51.5 & 0.61 & 548.33 & 127.25 & 1.11 & 0.87 \\
& SE & 1.71 & 0.55 & 0.72 & 0.03 & 0.03 & 1.34 & 0.02 & 20.37 & 5.50 & 0.01 & 0.01 \\
\multirow{2}{*}{ SG } & Mean & 46.79 & 2.50 & 10.15 & 0.37 & 0.34 & 56.16 & 0.66 & 459.50 & 141.5 & 1.15 & 0.91 \\
& SE & 4.73 & 1.17 & 4.91 & 0.11 & 0.18 & 9.63 & 0.07 & 95.49 & 37.00 & 0.06 & 0.08 \\
\multirow{2}{*}{ S } & Mean & 23.23 & 12.00 & 3.00 & 0.77 & 0.53 & 46.83 & 0.54 & 637.17 & 113 & 1.07 & 0.83 \\
& SE & 11.17 & 3.02 & 0.90 & 0.23 & 0.16 & 6.00 & 0.16 & 137.86 & 30.07 & 0.09 & 0.06 \\
\hline
\end{tabular}




\section{DISCUSSION}

Effect of village and farm proximity to gallery forests on fragmentation and structure of the gallery forests of $P$. butyracea

Gallery forest of $P$. butyracea and population of $P$. butyracea were interchangeable in our study. The distance village - gallery forest of $P$. butyracea was negatively correlated with the fruit harvest rate. The distance farm - gallery forest of $P$. butyracea was negatively correlated with fruit harvest rate and the gallery forest areas loss. These two facts showed that when NTFPs harvesters live near the source of NTFPs, more they are motivated to harvest in those populations and higher is the frequency to visit population and higher is the rate of harvest of NTFPs (Gaoue and Ticktin, 2007; Mamo et al., 2007). Our results suggested that a part from proximity of NTFPs (AvocèvouAyisso, 2011), the proximity of farm to forest ecosystems was a determinant of the higher rate of NTFPs harvest and habitat area loss. These correlations can be explained by the fact that anthropogenic pressures on forest ecosystems such as farms, wildfires, grazing and harvest increases when they are close to habitations.

Our findings showed that the rate of loss of forest gallery area over the last thirty years increases when dwellings are closer to gallery forests. The installation of habitations near the gallery forests are often associated with other sources of disturbance, in particular, the establishment of farms near the gallery forests (Natta, 2003) and the opening of the roads in these forests. The decrease of gallery forest area with the increase of the proximity of habitations and farms to gallery forests may lead to the reduction of vegetation cover or natural habitat of plant and consequently loss of biodiversity (Djohy et al., 2016). The proximity of habitation to forest ecosystems increase ecosystem fragmentation through others causes including logging, wildfires, grazing and cultivation (Bouko et al., 2007). High agricultural and livestock pressures lead to the destruction and fragmentation of gallery forests (Natta, 2003).
In addition, the width of the gallery is negatively correlated with the proximity of the various $P$. butyracea gallery forests and with the shape index of the gallery forests suggesting that nearest ecosystems are larger than far ecosystems. The current area of gallery forests is negatively correlated with their shape index and with their loss of area. The distance pedestrian roads- gallery forest of $P$. butyracea was negatively correlated with fruit harvest rate. This suggested that the presence of roads in forest may indicate the possible exploitation of that forest. Fruit harvest rate was positively correlated with the loss of area suggesting the combine effect of anthropogenic pressures such as harvest of NTFPs and reduction of habitat size. These results revealed that human pressures may be correlated. Reduction of habitat size due to fragmentation may affect individual plant fitness and thus the structure of plant population (Zambrano and Salguero-Gómez, 2014).

Our results revealed that the correlation between spatial isolation and habitat size, species diversity and population structure were not linear. Others studies found no linear significant correlation between habitat size and species richness (Digiovinazzo et al., 2010) or tree density and fragment size. In general, it is expected that the relationship between habitat size (area) and species richness is linear (Digiovinazzo et al., 2010). The deviation of the relationship from the linear relationship may be due to the natural or anthropogenic disturbances that have affected species richness (Digiovinazzo et al., 2010).

Effect of fragmentation on species diversity, tree density and size class distribution

The shape index of diameter class distribution in Sudanian zone ranged from 1.38 to 1.94 (Natta et al., 2011 a). In our study, it ranged from 0.68 to 1 in the Sudanian zone. In Sudano-guinean zone this shape ranged from 1.21 to 1.98 for all tree species (Natta et al., 2011 b). In our study, it ranged from 0.95 to 1.32 in the Sudano-guinean zone. 
These differences may be due to the differences in plot and sample size. Plot size affected significantly the shape parameter of diameter class distribution (Salako et al., 2013). Natta et al. (2011b) established plot of $500 \mathrm{~m}^{2}$ in Sudano-guinean zone, and in Sudanian zone Natta et al. (2011 a) used line transect of $100 \mathrm{~m}$. In our study we used a plot of $10000 \mathrm{~m}^{2}$. Natta et al. (2011a, 2011b) pooled diameter of many populations to determine the shape parameter whereas in ours we took only diameter of each population to compute the shape parameter. Our findings showed that the tree species diversity and density were also different from those of Natta et al. (2011a, 2011b).

Ecological zone had significant effects on the richness and diversity of $P$. butyracea gallery forest. This difference could be due to ecological differences between the two zones combined with disturbance levels in each zone. Species richness is higher in agroecological zones with low degradation (Bouko et al., 2007). In our study the number of species was high in Sudano-guinean zone than in Sudanian zone. In the later zone populations of $P$. butyracea were under high human pressure (Dicko et al., 2016). In addition, habitat loss reduced species diversity (Fahrig, 2003) but see Barima et al. (2012), and abundance (Barrios Roque et al., 2016). Moreover, the effect of anthropogenic pressures varies according to the ecological conditions (Gaoue and Ticktin, 2007). There was a significant negative effect of gallery area loss on $P$. butyracea tree density in the Sudano-guinean zone. The density is high in Sudano-guinean zone than in Sudanian zone. The high density of $P$. butyracea in the Sudano-guinean zone may be explained by the fact that this species is found in its ecological optimum, which is similar to the climate of humid zones of dense forest (Natta, 2003). Several factors such as light tolerance and life form (Tesfaye et al., 2003; Gaoue and Ticktin, 2007), climate and management (Tesfaye et al., 2003) affect tree density. Fires are recurrent and gallery forest of $P$. butyracea are under high human pressure in Sudanian zone than in Sudano-guinean zone. According to Biaou (2009), repeated vegetation fires combined with grazing would have a more negative impact on tree recruitment than each. Similarly, pressures on trees such as debarking of $P$. butyracea in Peperkou population may affect their potential for flowering and fruiting and then would affect regeneration and compromise the sustainability of $P$. butyracea tree species (Dicko et al., 2016). The shape parameter of the distribution of Weibull is a good indicator of population tree diameter structure. Our findings showed that the shape parameter was higher in Sudano-guinean zone than in Sudanian zone suggesting the abundance of trees with small diameter in the sub-humid zone, which was also less perturbed. The absence of significant effect of fragmentation on population structure of $P$. butyracea highlights the fact that $P$. butyracea increased clonal production in high disturbed habitat (Gaoue et al., 2018). This may increase the resilience of species to habitat size reduction (Gaoue et al., 2017).

\section{Conclusion}

This study examined the impact of fragmentation on the diversity, density and population structure of Pentadesma butyracea. Results showed that the rate of gallery forest area loss over the last 30 years increased when dwellings are installed closer to gallery forests. Moreover, it reveals that the combined anthropogenic disturbances interact with each other and lead to the reduction of habitat size, their fragmentation and consequently the loss of biodiversity. It also illustrates that fragmentation is a process that involves many interacting factors. Level of disturbance and ecological zones are determinants of species richness, density and population structure of $P$. butyracea. Particular attention must be paid to the management of fragmented habitats considering internal factors (population demography and dynamics) and external factors (anthropogenic factors). Further studies on the effects of habitat fragmentation on demographic processes and population dynamics in the two ecological zones would 
improve our understanding of anthropogenic disturbance effects.

\section{COMPETING INTERESTS}

The authors declare that they have no competing interests.

\section{AUTHORS' CONTRIBUTIONS}

MK designed and performed the field work, gave formal analysis and software, analyzed and drafted the manuscript; OEBA performed the field work and drafted the manuscript; TK read and improved the drafted manuscript; HSSB and AKN gave conceptual advice, supervised the work, read and improved the manuscript. All authors have read and approved the final manuscript.

\section{ACKNOWLEDGEMENTS}

We are grateful to Julien Kouagou, Claude Kouagou, Béranger Medeton, Mohamed Bouko, Rodrigue N'Koué, N'Félikan Chicke, Edmond Abley and N'Yama Simbia for field assistance.

\section{REFERENCE}

Adjonou K, Djiwa O, Kombate Y, Dzifa A, Kokou K. 2010. Etude de la dynamique spatiale et structure des forêts denses sèches reliques du Togo: implications pour une gestion durable des aires protégées. Int. J. Biol. Chem. Sci., 4: 168183. doi:10.4314/ijbcs.v4i1.5.

Adomou AC. 2005. Vegetation patterns and environmental gradedients in Benin Implications for biogeography and conservation. $\mathrm{PhD}$ thesis, Wageningen University, Wageningen, The Netherlands, $136 \mathrm{p}$.

Avocèvou-Ayisso CMA. 2011. Etude de la viabilité des populations de Pentadesma butyracea Sabine et de leur socioéconomie au Bénin. These de Doctorat, Université d'Abomey-Calavi, Benin. 223 pages

Barima SS, Angaman MD, De Canniere C, Bogaer J. 2012. Influence of forest degradation on tree diversity in a forestsavannah transition in Eastern Ivory Coast. Int. J. Biol. Chem. Sci., 6(4): 1467-1479. doi:http://dx.doi.org/10.4314/ijbcs.v6i4.6

Barrios Roque B, Koptur S, Sah JP. 2016. The effects of habitat fragmentation on the reproduction and abundance of Angadenia berteroi. J. Pl. Ecol., 10(2): 340-348.

Biaou SSH. 2009. Tree recruitement in West African dry woodlands: The interactive effects of climate,soil,fire and grazing. $\mathrm{PhD}$ thesis, Wageningen University, Wageningen, The Netherlands, $182 \mathrm{p}$.

Bouko BS, Sinsin B, Soulé BG. 2007. Effets de la dynamique d' occupation du sol sur la structure et la diversité floristique des forêts claires et savanes au Bénin. Tropicultura, 4: 221-227.

Brudvig LA, Damschen EI, Haddad NM, Levey DJ, Tewksbury JJ. 2015. The influence of habitat fragmentation on multiple plantanimal interactions and plant reproduction. Ecology, 96(10): $\quad$ 2669-2678. doi:10.1890/14-2275.1

Cribari-Neto F, Zeileis A. 2010. Beta Regression in R. Journal of Statistical Software, 34(2): 1-24. URL http://www.jstatsoft.org/v34/i02/.

Dan CBS, Sinsin BA, Mensah GA, Lejoly J. 2012. Influence des activités anthropiques sur la diversité floristique des communautés végétales de la forêt marécageuse de Lokoli au Sud-Bénin. Int. J. Biol. Chem. Sci., 6(6): 3064-3081. doi:http://dx.doi.org/10.4314/ijbcs.v6i6.8

Dicko A, Biaou SSH, Natta AK, Aboudou Salami CG, Kouagou MM. 2016. Influence des pressions anthropiques sur la structure des populations de Pentadesma butyracea au Bénin. VertigO: La Rev. Électronique en Sci. l'Environnement 16: 1-21. http://journals.openedition.org/ vertigo/18195.

Digiovinazzo P, Francesco G, Bottoni L, Andreis C, Padoa-schioppa E. 2010. Ecological thresholds in herb communities for the management of suburban fragmented forests. Forest Ecology and Management, 259: 343-349. doi:10.1016/j.foreco.2009.10.027

Ewédjè EBK, Natta A, Hardy OJ. 2012. Morphological variability of the tallow tree, Pentadesma butyracea Sabine (Clusiaceae), in Benin. Genet Resour Crop Evo., 53. doi:10.1007/s10722-012-9802-1.

Fahrig L. 2003. Effects of habitat fragmentation on biodiversity. Annu. Rev. Ecol. Syst., 34: 
487-515. doi:10.1146/annurev.ecolsys. 34.011802.132419.

Gaoue OG, Gado C, Natta AK, Kouagou M. 2018. Recurrent fruit harvesting reduces seedling density but increases the frequency of clonal reproduction in a tropical tree. Biotropica, 50(1): 69-73. doi:10.1111/btp.12486

Gaoue OG, Kouagou M, Natta AK, Gado C. 2017. Response of a tropical tree to nontimber forest products harvest and reduction in habitat size. PLoS One, 12: 35. doi:10.1371/journal.pone.0183964.

Gaoue OG, Ticktin T. 2007. Patterns of harvesting foliage and bark from the multipurpose tree Khaya senegalensis in Benin : Variation across ecological regions and its impacts on population structure. Biol. Conserv., 37: 424-436. doi:10.1016/j.biocon.2007.02.020.

Maazou R, Rabiou H, Issiaka Y, Abdou L, Idi Saidou S, Mahamane A. 2017. Influence de l'occupation des terres sur la dynamique des communautés végétales en zone Sahélienne: cas de la commune rurale de Dantchandou (Niger). Int. J. Biol. Chem. Sci., 11(1): 79-92. doi: http://dx.doi.org/10.4314/ijbcs.v11i1.7

Mamo G, Sjaastad E, Vedeld P. 2007. Economy dependence on forest resources: a case from Dendi District,Ethiopia. For. Policy Econ., 9 : 916-927. doi:10.1016/j.forpol.2006.08.001.

Marie B, Nacoulma I, Schumann K, Bernhardtro M. 2011. Impacts of land-use on West African savanna vegetation : a comparison between protected and communal area in Burkina Faso. Biodivers. Conserv. doi:10.1007/s10531-011-0114-0.

Natta AK. 2003. Ecological assessment of riparian forests in Benin: Phytodiversity, phytosociology, and spatial distribution of tree species. $\mathrm{PhD}$ thesis, Wageningen University, Wageningen, The Netherlands. $226 \mathrm{p}$.

Natta AK, Adomou AC, Tchabi VI, Sogbegnon AR, Mensah GABA. 2011a. Inventaire, typologie et structure des populations naturelles de Pentadesma butyracea (Clusiaceae) de la chaîne de l'Atacora au Nord-Ouest du Bénin. Bul. la Rech. Agron. du Bénin, 70: 10-24.

Natta AK, Yédomonhan H, Zoumarou-Wallis $\mathrm{N}$, Houndehin J, Ewédjè EBK, Glèlè kakai, RL. 2011b. Typologie et structure des populations naturelles de pentadesma butyracea dans la zone soudano-guinéenne du Bénin. Ann. des Sci. Agron., 15: 217243.

R Core Team 2017. R: A Language and Environment for Statistical Computing. Vienna, Austria. [Online] Available: https://www.r-project.org/.

Salako VK, Glele Kakaï RL, Assogbadjo AE, Fandohan B, Houinato M, Palm R. 2013. Efficiency of inventory plot patterns in quantitative analysis of vegetation: A case study of tropical woodland and dense forest in Benin. South. For., 75: 137-143. doi:10.2989/20702620.2013.816232.

Sama B, Sacandé M, Schmidt LH. 2007. Pentadesma butyracea Sabine. Seed Leafl: Copenhagen

Tesfaye G, Teketay D. Fetene M. 2003. Regeneration of fourteen tree species in Harenna forest, southeastern Ethiopia. Flora, 197: 461-474. doi:10.1078/03672530-1210063.

Yabi BF, Lougbegnon TO, Codjia JTC. 2017. Influences des Zones Biogéographiques sur la Diversité Avienne des Galeries Forestières au Bénin, Afrique de 1 'Ouest. Eur. Sci. J., 13: 410-438. doi:10.19044/esj.2017.v13n6p410.

Yeo K, Tiho S, Ouattara K, Konate S, Maurice LM. 2013. Impact de la fragmentation et de la pression humaine sur la relique forestière de l'niversité d 'Abobo-Adjamé (Côte d'Ivoire). J. Appl. Biosci., 3: 45514565. doi:10.4314/jab.v61i0.85602.

Zambrano J, Salguero-Gómez R. 2014. Forest fragmentation alters the population dynamics of a late-successional tropical tree. Biotropica, 46: 556-564. doi:10.1111/btp.12144. 